\title{
CHARACTERISTICS OF STRUCTURAL COMPONENTS, CRITERIA AND INDI- CATORS, LEVELS OF FORMATION OF VALUE-SEMANTIC EXPERIENCE OF FUTURE SPECIALISTS IN FOREIGN PHILOLOGY
}

\section{Liliia Svyshch}

Changing axiological guidelines is a fundamental topic for higher education. In particular, the modern professional training of future foreign philologists cannot ignore the need to turn to axiological discourse. The need for special attention to axiological issues in the context of professional training of specialists of the relevant profile led to the definition of pedagogical conditions for the formation of value-semantic experience of these specialists. The implementation of such pedagogical conditions is ensured, including by the evaluation of the achieved results. The latter determines the research interest in the elements of diagnosis - components, criteria, indicators and levels of their implementation. The purpose of the research is to practically define and substantiate the components of the formation of value-semantic experience, the criteria, corresponding to them, the indicators characteristic of the criteria and the levels of their manifestation are determined. Achieving this goal involves (1) determining these elements of the diagnosis of the formation of a certain competence (or desired quality) and (2) their practical justification.

The generalized research experience shows that the diagnosis of the formation of certain competencies (individual qualities) is usually accompanied by the selection of components of cognitive, motivational (value-motivational), operational-activity (functional-activity) and organizational. Taking into account the practice of applying the competence approach to determine the criteria in the work, the criteria of formation of value-semantic experience of future specialists in foreign philology are applied: cognitive, value-motivational, operational-activity, organizational with corresponding indicators, as well as certain levels of their manifestation.

The researched and substantiated elements of diagnosis open the way to practical modeling of the structural and semantic model of the process of formation of value-semantic experience of future specialists in foreign philology

Keywords: specialists in foreign philology, axiology, value education, diagnostics of personality qualities formation

How to cite:

Svyshch, L. (2021). Characteristics of structural components, criteria and indicators, levels of formation of value-semantic experience of future specialists in foreign philology. ScienceRise: Pedagogical Education, 3 (42), 46-52. doi: http://doi.org/10.15587/2519-4984.2021.234009

(C) The Author(s) 2021

This is an open access article under the Creative Commons CC BY license

\section{Introduction}

The changing world, and with it the change of axiological guidelines, is a fundamental topic for higher education. The importance of axiological research is determined by the fact that values and value orientations as leading elements of the value-semantic sphere of personality are important means of mastering the spiritual culture of society, and the inclusion of axiological approaches in the educational process is the key to transforming cultural values into stimuli and motives of future specialists' practical behavior. In particular, modern professional training of future foreign philologists can not ignore the need to turn to axiological discourse, because ensuring the orientation of students in the world of values creates the preconditions for the ascent of the student's personality to the values of society and their practical assimilation.

Based on a well-founded thesis on the need for special attention to axiological issues in the context of higher education, in particular, on the training of specialists in specialty 035 "Philology" we determined the pedagogical conditions for the formation of value-semantic experience of future professionals in the process of pro- fessional training, as well as the theoretical design of educational activities to ensure these conditions. It was proved, that the formation of value-semantic experience in the process of professional training is a complex pedagogical problem, the solution of which requires consideration of a system of interrelated factors that are fundamental for the results of the educational process [1].

The effectiveness of solving this problem is ensured by a qualitative and objective assessment of the achieved results, which determines the research interest in the phenomena, related to diagnostic methods, components of the formation of a certain competence (or desired quality) of a pedagogical specialist (including future foreign philologists). Just the elements of diagnosis - components, criteria, indicators and levels of their implementation, will be the subject of our further consideration.

\section{Literary review}

The need to identify specific components of the formation of a particular competence (or desired quality) is obviously due to the desire to comprehensively disclose the manifestation of certain competencies (or de- 
sired quality) in the personality structure and establish their correlations with the course and results of the educational process. Essential for the study is a reasonable position of a Ukrainian researcher Svitlana Protska, that "any model of assessment of competencies or their components must meet the following conditions: the main criteria (indicators) are determined, according to which it is possible to find out whether a student has mastered the knowledge and skills at a certain level; several levels of formation of competencies (or their components) are indicated; the procedure for evaluating learning outcomes is determined; the degree of formation of competencies (or their components) is established" [2].

A Ukrainian researcher Maryna Vasylieva also uses the method of isolating components of a certain competence (or desired quality) of a pedagogical specialist. She developed a theoretical model of the content of deontological training of teachers, which includes motivational-value, cognitive, procedural and analyticalreflexive components. The degree of formation of these components is associated with certain criteria of deontological readiness and their specific indicators [3].

In foreign practice, the method of separating components of a certain competence (or desired quality) is also used. For example, American researchers [4] have developed a component model of communication competence, consisting of three specific dimensions:

1) motivation (human approach or focus on avoidance in different social situations);

2) knowledge (action plans, knowledge of how to act; procedural knowledge);

3) skills (behavior that is actually performed).

Regarding the phenomenon of criteria, which is in fact a mandatory element of the diagnosis of the formation of certain competencies (individual qualities), the established interpretation of the concept of "criterion" is defined as signs, grounds, rules for deciding to assess something for compliance with the requirements (measures). Instead, in the research discourse [5] elaborating the criteria, indicators and levels of professional competence of social educators, the concept of "criteria" is reasonably interpreted as "a set of features and properties of the phenomenon, object, subject, which allow to judge its condition, level of development and functioning" [6]. Russian researchers in their classic work [6] point to the analytical significance of the criteria. The latter appear as a means of establishing between the complex components of the studied formation. In this case, the criteria should be determined through a set of specific features that reflect all the structural components, certifying the dynamics of quality, measured over time [7].

At the same time, the main point for diagnosing the formation of certain competencies (individual qualities) is to take into account the fact that the evaluation of each criterion is based on a set of indicators. Les us note that in the methodology of pedagogical diagnosis of the results of the educational process, the indicator is interpreted as a qualitative or quantitative characteristic of a certain criterion. Criteria (the fact of their implementation) can be manifested in several indicators simultaneously. It is important to note, that "criteria and indicators are in unity and interrelation, confirming the systematici- ty and integrity of the studied phenomenon, as well as the presence of correlations between them" [8].

Meanwhile, it should be emphasized, that a level approach is used as a diagnostic tool. Establishing the levels of formation of certain competencies (individual qualities) allows to obtain a general objective picture of the relevant educational process, the effectiveness of the implementation of the developed pedagogical conditions. In practice, virtually each stage of formation of certain competencies (individual qualities) is characterized by the end result, which is reflected in the level of formation of knowledge, skills and abilities and provides the potential for professional activity.

Summarizing the literature review, we note that the theoretical analysis of the concepts "criteria", "indicators" and "levels" is a methodological condition for their determination of the formation of value-semantic experience of future specialists in foreign philology in training. Note that a special analysis, carried out by us at the preparatory stage of the study, showed that so far there have been no attempts to investigate the formation of valuesemantic experience of future specialists in 035 "Philology", as well as diagnosis of this quality in future philologists. Meanwhile, the objective diagnosis of the formation of value-semantic experience of future specialists in foreign philology in the process of training provides an information basis for quality educational activities in the axiological context in the process of training specialists in this field.

\section{The aim and objectives of the study}

The aim of the research is to practically define and substantiate the components of the formation of value-semantic experience, the criteria, corresponding to them, the indicators, characteristic to the criteria and the levels of their manifestation.

To achieve this aim, the following objectivesare accomplished:

1. Determination of the specified elements of diagnostics of formation of a certain competence (or desirable quality).

2. Their practical justification.

\section{Materials and methods}

The paper uses a significant amount of research practice materials on the issue of analysis of the formation of a certain competence (or desired quality). The main methods of the presented research are analysis and content analysis, as well as other general theoretical and analytical methods of scientific research, which provided an opportunity to solve the formulated scientific problems.

\section{Research results and their discussion}

The generalized research experience shows that the diagnosis of the formation of certain competencies (individual qualities) is usually accompanied by the selection of components of cognitive, motivational (value-motivational), operational-activity (functionalactivity) and organizational ones. These components are a system unit, each element of which has certain typical characteristics:

1) cognitive (knowledge possession) is characterized by the acquisition of knowledge (general, profile or 
special plan); there is a need for training as the main source of knowledge; characteristic idea of the specifics of the future profession;

2) motivational (value-motivational) component (stimulation to personal growth) is typically characterized by internal motivation to master professional competencies; the importance of the profession and professional competencies is recognized; the need to master innovative educational technologies is recognized; motivation for a successful career;

3) operational-activity (functional-activity) component (practicality of knowledge) is characterized by the presence of skills in practice to implement professional knowledge; to carry out self-reflection on own professional competences and ability to realize them; creativity in the context of professional activity;
4) organizational component (logistic-mobilizing) is represented by the ability to organize effective selflearning and acquisition of professional competencies; ability to apply various means, forms and methods of increasing an individual educational and professional level; shows the prospects and methods of improving the efficiency of the educational process.

Note that all the above described components of the formation of certain competencies (individual qualities) are standard means of diagnosing the results of the educational process and are widely used in research practice. Within the tasks of our research - to diagnose the formation of value-semantic experience of future specialists in the specialty 035 "Philology", we consider it reasonable to make a meaningful clarification of the relevant components, which is reflected in the Table 1.

Table 1

Characteristics of the components of the formation of value-semantic experience of future specialists in the specialty 035 "Philology"

\begin{tabular}{|l|l|l|l|}
\hline No. & \multicolumn{1}{|c|}{$\begin{array}{c}\text { Component } \\
\text { name }\end{array}$} & Component essence & \multicolumn{1}{c|}{ Typical characteristics } \\
\hline 1 & cognitive & $\begin{array}{l}\text { Possession of } \\
\text { knowledge }\end{array}$ & $\begin{array}{l}\text { mastering axiological knowledge; } \\
\text { the need for value training as an important source of axiology; } \\
\text { characteristic idea of the specifics of the future profession. }\end{array}$ \\
\hline 2 & motivational & $\begin{array}{l}\text { Stimulation to pro- } \\
\text { fessional growth }\end{array}$ & $\begin{array}{l}\text { intrinsic motivation to master axiological competencies; } \\
\text { awareness of the value of the profession and professional competen- } \\
\text { cies; value-motivated need to master innovative educational tech- } \\
\text { nologies; } \\
\text { motivation for a successful career as a life and professional value. }\end{array}$ \\
\hline 3 & $\begin{array}{l}\text { Operational- } \\
\text { activity }\end{array}$ & $\begin{array}{l}\text { Practicality of } \\
\text { knowledge } \\
\text { activities; } \\
\text { the ability to self-reflect on own axiological competencies and the } \\
\text { ability to implement them; } \\
\text { creativity in the application of axiological competencies in the con- } \\
\text { text of professional activity. }\end{array}$ \\
\hline 4 & $\begin{array}{l}\text { organizational } \\
\text { Logistic-mobilizing }\end{array}$ & $\begin{array}{l}\text { ability to organize effective independent acquisition of axiological } \\
\text { competencies; } \\
\text { ability to apply various means, forms and methods of increase of an } \\
\text { individual educational and professional level. }\end{array}$ \\
\hline
\end{tabular}

The described components of the formation of the value-semantic experience of future specialists in foreign philology govern the methodological basis for evaluating the achievement of the results, stated in our study. It should be noted, that as a diagnostic tool we use the method of assessment through a system of criteria and indicators in combination with a level approach.

Regarding the phenomenon of criteria, which is in fact a mandatory element in diagnosing the formation of certain competencies (individual qualities), it should be noted that the Ukrainian researcher gives criteria a normative-motivational function, because the concept of "criterion" is interpreted as a characteristic of what a student should do and a way to demonstrate his/her educational achievements [9]. At the same time, the researcher from the experience of researching the process of forming control of professional knowledge of future foreign language teachers, points out that the criteria must meet certain requirements that ensure their analytical adequacy: informativeness, objectivity, neutrality, the possibility of qualitative description [8].
Taking into account the developed material on the practice of using criteria as diagnostic tools for the formation of certain competencies (individual qualities), we note that in our study they will act as tools for assessing various aspects of the formation of value-semantic experience of future specialists in foreign philology. At the same time, the criteria will perform not only analytical, but also normative-motivational functions, as they will contribute to the answers to the questions:

1) how is the formation of value-semantic experience?

2) how to carry out this process more effectively?

In methodological terms, the definition of criteria for the formation of value-semantic experience of future specialists in foreign philology is based on a competency-based approach. The study of the practice of applying this approach shows that researchers usually use the following criteria:

1) cognitive;

2) value-motivational;

3) operational-activity;

4) organizational. 
As shown in Table 2, these criteria reflect the specifics of the formation of spiritual qualities of the individual within the educational objectives, provided by the relevant educational programs of professional training.

Table 2

Criteria that are typically used to determine the formation of certain competencies (individual qualities) based on the results of the educational process

\begin{tabular}{|c|l|l|}
\hline No. & \multicolumn{1}{|c|}{ Author and research subject } & \multicolumn{1}{|c|}{ Criteria } \\
\hline 1 & $\begin{array}{l}\text { I. Kohut: formation of professional and pedagogical communicative competence of } \\
\text { the future teacher [10]. }\end{array}$ & $\begin{array}{l}\text { Motivational-value; } \\
\text { cognitive; } \\
\text { activity. }\end{array}$ \\
\hline 2 & $\begin{array}{l}\text { O. Postilna: formation of moral values of students of pedagogical universities by } \\
\text { means of information and communication technologies [11]. } \\
\text { instrumental- } \\
\text { informational, } \\
\text { emotional- } \\
\text { motivational, } \\
\text { activity-action, } \\
\text { ethical-communicative. }\end{array}$ \\
\hline 3 & $\begin{array}{l}\text { O. Gnedkova: formation of control of professional knowledge of future teachers of } \\
\text { foreign languages in the process of distance learning [9]. }\end{array}$ & $\begin{array}{l}\text { motivational, } \\
\text { linguosociocultural, } \\
\text { methodical, } \\
\text { computer science. }\end{array}$ \\
\hline 4 & $\begin{array}{l}\text { S. Protska: formation of professional and pedagogical competence of future teachers } \\
\text { of philology [12]. }\end{array}$ & $\begin{array}{l}\text { motivational-target, } \\
\text { professional-cognitive, } \\
\text { professional-activity, } \\
\text { reflexive-evaluative }\end{array}$ \\
\hline 5 & $\begin{array}{l}\text { S. Galetsky: formation of communicative competence of future teachers of foreign } \\
\text { languages by means of information and communication technologies [13]. } \\
\text { cognitive, } \\
\text { motivational, } \\
\text { activity. }\end{array}$ \\
\hline
\end{tabular}

Taking into account the practice of applying the competency approach to determine the criteria of certain competencies (individual qualities), we'll further apply the following criteria for the formation of value-semantic experience of future specialists in foreign philology: cognitive, value-motivational, operational, organizational. These criteria allow us to understand whether the process of formation of value-semantic experience as a result of the implementation of our proposed pedagogical conditions:

1) formation of the knowledge base of value motivations in the professional activity of future philologists;

2) development of the value-semantic sphere of students of philological education by creating an axiooriented educational environment;

3) formation of operational and activity skills of realization of axiological knowledge and value priorities in future philologists;

4) mastering the methods of evaluation and adjustment of professional activity in terms of implementation of axiological knowledge and value priorities.

In addition, these criteria provide monitoring of mastering of a number of professionally important values by future specialists in the specialty 035 "Philology" in the field of knowledge 03 "Humanities" of the first (bachelor's) level:

1) values of cognitive content,

2) values that define the identity of the teacher,

3 ) values that determine the content of relations in the education system.
Thus, the criterion of the cognitive component is "mastering of axiological knowledge, categoricalconceptual apparatus of value theory, acquaintance with the peculiarities of professional values", respectively, its indicators are conscious knowledge and understanding:

1) features of axiological knowledge, its origin, specifics of disciplinary formation, conceptual design, subject load, scientific and practical potential;

2) specifics and philosophical-theoretical interpretation of the main value phenomena (values, value orientations, value-semantic sphere, etc.);

3 ) content and functional load of axiological competencies;

4) semantic and value correlations between the specifics of professional activity, the features of professionally significant values and the content of value training as an important source of axiology.

The criterion of the motivational component is "internal motivation to acquire axiological competencies as a fundamental basis of value-balanced professional activity." Indicators of this criterion are:

1) understanding and awareness of the professional significance of axiological competencies for specialists in the specialty 035 "Philology";

2) presence of motivation to master axiological competencies and assimilation of professional values;

3) awareness of the need to master innovative educational technologies to improve professional competencies, including axiological ones.

The criterion of the operational component is "practical skills to implement axiological knowledge and 
act in a value-wise manner in professional activities", and the relevant indicators are:

1) assimilation of values and awareness of value orientations as the basis of life;

2) ability to implement axiological competencies in life practice and professional activity;

3) ability to act in a situation of value conflicts and value choices on the basis of axiological competencies;

4) ability to self-reflect on own axiological competencies and the ability to implement them.

The criterion of the organizational component is "systemic actions of cognitive orientation, focused on the independent acquisition of axiological knowledge and value experience, useful in a professional context." Indicators of this criterion are:

1) ability to organize effective independent acquisition of axiological competencies as important learning outcomes;

2) ability to apply various means, forms and methods of increase of an individual educational and professional level; perience;

$3)$ conscious desire to gain valuable practical ex-

4) logistic approach to the organization of value self-education and creativity in the application of its achievements (axiological knowledge and value experience).

Note that these criteria and indicators are interrelated and are a means of effective diagnosis of the formation of value-semantic experience of future professionals in the specialty 035 "Philology".

The next stage of our study, after determining the criteria and their indicators, is to develop levels of valuesemantic experience of future specialists in foreign philology in the process of training. The implementation of this research stage is based on the principle, according to which each criterion is met by a system of indicators, as distributed according to their actual levels. It should be noted, that a Ukrainian scientist Semyon Goncharenko, reflecting on the problem of diagnosing the criteria and indicators of a certain phenomenon, came to the conclusion that any object under study can have several levels of development. At the same time, in his methodical work [14], which does not lose relevance today, S. Goncharenko emphasizes that distinguishing such levels it is necessary to follow certain rules:

1) levels should provide a clear indication of the development of the object;

2) each new level must clearly record the degree of development of the object;

3 ) there must be a relationship and a certain correlation between the selected levels of development of the object, which reflects the process of development of the object [14].

Finally, the analysis of the use of the level approach in the research of different scientists testifies to the practice of using the three-level ranking of the formation of certain competencies (individual qualities):

1) low level (ability to reproduce certain knowledge);

2) medium (or sufficient) level (ability to reproduce and use existing knowledge and skills);
3) high (ability to be creative in the use of acquired knowledge and skills).

Taking into account all the above and on the basis of existing research experience of ranking indicators for assessing the formation of certain competencies (individual qualities), it is reasonable to determine the author's levels of implementation of indicators of criteria for the formation of value-semantic experience of future specialists in foreign philology in the process of professional training: high, medium and low. Here are the characteristics of each of these levels.

Low level is characterized by:

a) insufficient understanding of the features of axiological knowledge; insufficient understanding of the content and functions of axiological competencies; weak understanding of professionally significant values and the content of value training;

b) insufficient motivation to master axiological competencies and assimilate professional values; weak awareness of the need to master educational technologies for professional development;

c) poor assimilation of values and awareness of value orientations as a basis of life; lack of skills to implement axiological competencies in life practice and professional activity; inability to self-reflect on own axiological competencies;

d) inability to systemic actions of cognitive orientation, focused on the independent acquisition of axiological knowledge and value experience.

Middle level is characterized by:

a) understanding the features of axiological knowledge, its origin, the specifics of disciplinary formation; partial mastery of the conceptual apparatus of axiology; weak understanding of professionally significant values and the content of value training;

b) the formed motivation to master axiological competencies and assimilation of professional values; awareness of the need to master educational technologies for professional development;

c) assimilation of values and awareness of value orientations as a basis of life; the idea of the need for self-reflection on own axiological competencies.

High level is characterized by:

a) understanding the features of axiological knowledge, its origin, the specifics of disciplinary formation; possession of the conceptual apparatus of axiology; understanding the content and functions of axiological competencies; conviction about the professional significance of value training as an important source of axiology;

b) motivation to master axiological competencies and assimilation of professional values; desire to master educational technologies for professional development;

c) assimilation of values and awareness of value orientations as a basis of life; creative approach to the practical implementation of axiological competencies in professional activities; ability to self-reflect on own axiological competencies;

d) ability to system actions of cognitive orientation, focused on independent acquisition of axiological knowledge and value experience, ability to organize an increase of an individual educational and professional level; involving a logistic approach to the organization of 
value self-education and creativity in applying its achievements.

We emphasize that with the help of certain criteria and indicators, and their levels, it is possible to assess the educational and methodological potential and prospects of the above pedagogical conditions for the formation of value-semantic experience of future professionals in the specialty 035 "Philology" in the field of knowledge 03 "Humanities" (bachelor's) level in the process of professional training. Research (diagnosis and analysis) of the results of professional training of future specialists in foreign philology proves the possibility of the implementation of our developed pedagogical conditions for the formation of value-semantic experience and related axiological competence, which involves:

1) possession of axiological knowledge and understanding, i.e. ability to know and understand;

2) knowledge of how to act in a situation of value conflict and value choice;

3 ) assimilation of values and awareness of value orientations as a basis of life (in particular, professional activity).

The principal educational result of realization of the pedagogical conditions, developed by us, is also to provide mastering by future experts of a specialty 035 "Philology" of system of values, fundamental for the modern philologist:

1) values of the knowledge content;

2) values, defining the teacher's personality;

3 ) the content of relations in the education system.

Finally, the elements of diagnosis - components, criteria, indicators and levels of their implementation, researched and substantiated by us, open the way to practical modeling of the structural-semantic model of the process of formation of value-semantic experience of future specialists in foreign philology. In this case, these elements of diagnosis correlate with the genesismodeling method, which is designed to provide a growing individual with a holistic educational strategy. This method is aimed at "both the model (ideal representation) of a particular personal formation (values) and the optimal way to achieve it" [15]. In addition, this method allows a subject of pedagogical activity to achieve systematization in the organization of their own behavior at the stage of perception of the surrounding reality in interaction in a specially defined pedagogical environment, as well as at the stage of selective acceptance of spiritual value (ethical requirement).

Modeling the process of forming the valuesemantic experience of future specialists in foreign philology and the relevant pedagogical environment is more relevant today than ever, because, as Spanish researchers rightly point out, "in today's world, where violence and lack of solidarity and ethical behavior have become commonplace, it becomes more and more necessary to create spaces for dialogue, thoughts and reflections, in which these values can develop" [16]. Therefore, educational communities should be actively involved in the development of educational projects (appropriate models), within which acquaintance, perception and interaction with the values of solidarity, tolerance, respect for differences and ideological and cultural diversity will become common practice.

\section{Conclusions}

Based on the stated aims and research tasks, we have identified and processed the components of the formation of value-semantic experience, the corresponding criteria, indicators, characteristic to the criteria and determined the levels of their manifestation. In particular, based on the results of the study, we came to the following conclusions and generalizations:

1. The components of the formation of valuesemantic experience of future specialists of the specialty 035 "Philology" can be considered: a) cognitive (mastery of axiological knowledge); motivational (stimulation to personal growth); operational (practical knowledge); organizational (logistic and mobilizing). The described components of the formation of the value-semantic experience of future specialists in foreign philology govern the methodological basis for evaluating the achievement of the results, stated in our study.

Taking into account the practice of applying the competence approach to determine the criteria of certain competencies (individual qualities), we will reasonably apply the following criteria for the formation of valuesemantic experience of future specialists in foreign philology: cognitive, value-motivational, operational, organizational. These criteria allow us to understand whether there is a process of formation of value-semantic experience as a result of the implementation of our proposed pedagogical conditions.

2. The paper substantiates that:

- the criterion of the cognitive component is "mastery of axiological knowledge, categoricalconceptual apparatus of value theory, acquaintance with the peculiarities of professional values";

- the criterion of the motivational component is "internal motivation to acquire axiological competencies as a fundamental basis of value-balanced professional activity";

- the criterion of the operational-activity component is "practical skills to implement axiological knowledge and act in a value-wise manner in professional activities";

- the criterion of the organizational component is "systemic actions of cognitive orientation, focused on the independent acquisition of axiological knowledge and value experience, useful in a professional context."

These criteria and their corresponding indicators are interrelated and are a means of effective diagnosis of the formation of value-semantic experience of future specialists in the specialty 035 "Philology".

Based on the existing research experience of ranking indicators of criteria for assessing the formation of certain competencies (individual qualities) it is reasonable to determine the author's levels of implementation of indicators of criteria for the formation of value-semantic experience of future specialists in foreign philology in training: high, middle and low.

The research (diagnosis and analysis) of the results of professional training of future specialists in foreign philology proves the possibility of the implementation of our developed pedagogical conditions for the formation of value-semantic experience and related axiological competence. 


\section{References}

1. Svyshch, L. O. (2021). Tsinnisno-smyslovyi dosvid yak umova formuvannia aksiolohichnoi kompetentnosti. Grail of Science, 1, 428-430. doi: http://doi.org/10.36074/grail-of-science.19.02.2021.090

2. Protska, S. M. (2019). Kompiuterno oriientovana metodyka formuvannia profesiino-pedahohichnoi kompetentnosti maibutnikh uchyteliv-filolohiv. Kyiv, 304.

3. Vasylieva, M. P. (2004). Teoretychni osnovy deontolohichnoi pidhotovky pedahoha, 38.

4. Spitzberg, B. H., Cupach, W. R. (1984). Interpersonal Communication Competence. Beverly Hills: Sage, 236. Available at: https://scirp.org/reference/referencespapers.aspx? referenceid=2021723

5. Chubuk, R. V. (2008). Kryterii, pokaznyky ta rivni profesiinoi kompetentnosti sotsialnykh pedahohiv. Naukovi zapysky Natsionalnoho universytetu "Ostrozka akademiia". Seriia: Psykholohiia i pedahohika, 11, 253-263.

6. Slastenin, V. A., Podymova, L. S. (1997). Pedagogika. Innovatsionnaya deyatelnost. Moscow: Magistr, 223.

7. Molchaniuk, O. V. (2020). Theoretical-methodological foundations of training values-based attitude to the nature of future biology teachers. Kyiv, 469.

8. Hniedkova, O. O. (2017). Pedahohichni umovy formuvannia kontroliu fakhovykh znan maibutnikh uchyteliv inozemnykh mov u protsesi dystantsiinoho navchannia. Kherson, 294.

9. Samborska, E. V. (2015). Criteria, indexes and levels of readiness of master's degrees of technologicaleducation to monitoring of educational achievements of students. Naukovyi chasopys Natsionalnoho pedahohichnoho universytetu imeni M. P. Drahomanova. Seriia 5. Pedahohichni nauky: realii ta perspektyvy, 51, 239-244. tava, 250 .

10. Kohut, I. V. (2015). Formuvannia profesiino-pedahohichnoi komunikatyvnoi kompetentnosti maibutnoho vchytelia. Pol-

11. Postylna, O. O. (2016). Formuvannia moralnykh tsinnostei studentiv pedahohichnykh universytetiv zasobamy informatsiino-komunikatsiinykh tekhnolohii. Melitopol, 223.

12. Protska, S. M. (2019). Kompiuterno oriientovana metodyka formuvannia profesiino-pedahohichnoi kompetentnosti maibutnikh uchyteliv-filolohiv. Kyiv, 304.

13. Galetskyi, S. M. (2020). The formation of communicative competence of future foreign language teachers by the means of information and communication technologies. Zhytomyr, 292.

14. Honcharenko S. U. (1995). Pedahohichni doslidzhennia: metodolohichni porady molodym naukovtsiam. Kyiv: APN Ukrainy, 47.

15. Bekh, I., Pelekh, Y. (2020). Genesis-modeling Method in the Educational Process. Journal of History Culture and Art Research, 9 (2), 90-105. doi: http://doi.org/10.7596/taksad.v9i2.2614

16. Pérez-Jorge, D., Barragán Medero, F., Molina-Fernández, E. (2017). A Study of Educational Programmes that Promote Attitude Change and Values Education in Spain. Asian Social Science, 13 (7), 112-130. doi: http://doi.org/10.5539/ass.v13n7p112

Received date 08.04.2021

Accepted date 18.05.2021

Published date 31.05.2021

Liliia Svyshch, Senior Lecturer, Departament of Ukrainian and Foreign languages, Lviv State University of Physical Culture named after Ivan Boberskyj, Kostiushka str., 11, Lviv, Ukraine, 79007

E-mail: lilyasvysch@ukr.net 